\title{
The impact of age on the customers buying behaviour and attitude to price
}

\author{
Marie Slabá \\ ${ }^{1}$ Institute of Technology and Business in České Budějovice, Faculty of Corporate Strategy, \\ Department of Tourism and Marketing
}

\begin{abstract}
Understanding consumer buying behaviour is a crucial element of any business activities. In a marketing-oriented economy, consumer buying behaviour represents a very significant factor in business success. Therefore, there are many studies, researches and papers focusing on this phenomenon. Many different factors and characteristics have a positive or negative impact on consumer buying behaviour. Studying and understanding these factors contributes to a better understanding of consumer behaviour. Personal and socio-demographic characteristics like age, lifestyle, occupation, and many other significantly influence consumer buying behaviour. This article focus especially on age as a significant factor influencing consumer buying behaviour and customer attitude to price. For the statistical analysis of the impact of the age on consumer behaviour, one-way ANOVA will be used. Stated hypotheses on attitude to branded and non-branded goods will be analysed by chisquared test.
\end{abstract}

Keywords: consumer buying behaviour, age, price, customer loyalty.

\section{Introduction}

Like any other people's behaviour, consumer buying behaviour can be seen as determined by many factors. Companies oriented on their customers represent companies seeking to customer satisfaction. These companies are not looking to sell but for long-term consumer satisfaction by providing products of high quality with their own continued survival and long term goal of the company (Haghshenas et al. 2013). 
Since any customer is an individual person, there are lots of different factors influencing the customer buying decision. For many decades, consumer buying behaviour captured the imagination of researches all over the world. Understanding buying behaviour is one of the critical elements of success of any business activity. Therefore, many types of research are interested in understanding consumer buying behaviour for many decades. Understanding consumer buying behaviour enables better forecasting and understanding purchasing habits and motives (Stávková, Stejskal, and Toufarová 2008). Customer buying behaviour has long been of interest to organizations, researchers, and customers. Generally, consumer behaviour represents consumer buying behaviour during any buying process.

Today, many scientific papers and researches are focusing on the consumer buying behaviour and different factors that the consumer buying behaviour influence (e.g., Durmaz 2014, Stávková, Stejskal, and Toufarová 2008, Khaniwale 2015, Chhabra 2018, Kumar, Hundal and Kaur 2019 and many others). Some authors — for example, McGuiere (1976), or Lawan and Zanna (2013) distinguish internal and external factors that influence customer decisions. Internal factors are mainly represented by psychological and socio-demographic characteristics, and external factors are mainly represented byproducts or service variables.

Many researchers (e.g. Rehman, Yusoff, Zabri and Ismail 2017, Rani 2014, Lichev 2017, Durmaz 2014, Martins, Yusuf, \& Swanson 2011, Cranfield, Henson and Blandon 2012, Ostrovskiy, Garkavenko and Rybina 2019) focus on the influence of psychological and sociodemographic variables on customers' purchasing behaviour, as they play an important role in purchasing decisions. Khaniwale (2015), as well as Sukdeo (2018) and Yakup and Jablonsk (2012), suggest that is necessary to take into account personal characteristic of the customer since each customer as an individual is unique by personal characteristics and nature. Rani (2014) states that it is crucial to know that lots of factors influencing buying behaviour derive from psychology, and it is necessary to understand these factors to understand consumer buying behaviour. These characteristics shape a person as an individual, and influence his or her view of the world, ways of making decisions, including purchasing decisions. As stated Rani (2014), psychological and socio-demographic characteristics like age, annual income, economic conditions, occupation, or personal lifestyle, and many others have a significant influence on the consumer buying behaviour as each individual is a unique person with unique personal characteristics. Based on many types of research, it is clear that social, cultural, personal, and psychological characteristics influence directly marketing strategy (Sukdeo 2018). Marketing starts with the needs, wants, and desires of the consumer and finishes with the satisfaction of these needs and wants, and desires to achieve companies' goals (Dumaz 2014).

Age is considered to be one of the key demographic factors that influence customer purchasing behaviour. Rani (2014) states that age is a significant factor for marketing strategy since age creates a critical difference among consumer choices and consumers' consumption habits and patterns. Although age is considered to be one of the most 
significant factors of consumer behaviour, there are not too many scientific studies and articles that focus exclusively on these socio-demographic characteristics (e.g., Hervé and Mullet 2009, Rani 2014). Therefore, the author, in her research, focused on demographic variables and their influence on consumer purchasing behaviour and preferences in the choice of products and services. This article aims to examine the impact of age on customer perception of price, as the price is also one of the main factors that the customers evaluate in their purchasing decision process.

\section{Theoretical background}

Any business entity studies consumer buying behaviour to obtain crucial information on the consumer decision process and choice of products and services. This information is a crucial element for a successful marketing strategy that is developed based on the understanding of consumers buying behaviour needs and wants (Łatuszyńska, Furaiji and Wawrzyniak, 2012, Sukdeo 2018, Haghshenas, Abedi and Ghorbani 2013).

Many authors started to study consumer buying behaviour during the 1950s-1960s. First theoretical postulates claim that consumer buying behaviour represents a function of needs, beliefs, and desires that are connected to individual behaviour and represent the predominant determinant of personal actions and intentions (Łatuszyńska, Furaiji and Wawrzyniak, 2012).

As stated Haghshenas, Abedi and Ghorbani (2013), generally speaking, consumer buying behaviour studies how and why customers buy or not to buy any product. There are many definitions of consumer behaviour since there are several different approaches adopted in the study of customer buying behaviour. The main theories studying follows - Ajzen's theory of planned behaviour, Alphabet theory, ABC (Attitude-Behaviour-Context) theory, VBN (Value-Belief-Norm) theory or VAB (Value-Attitude-Behaviour), Theory of reasoned action, EKB model Motivation-need Theory and many others (Zepeda - Deal 2009, Tan 2011). Each theory tries to explain consumer buying behaviour based on different approaches and factors. For example, VAB model is a prevalent model used in green buying behaviour studies (Tan 2011). VAB model implies that any influence could theoretically flow from the abstract values to specific buying behaviour since values can influence attitude and attitude can influence behaviour (Homer - Kahle 1988). Sharma (2014) claims that consumer buying behaviour is the consumer decision process and following acts of people involved in searching, choosing, buying, and using products. Dawson, Findlay, and Sparks (2008) define consumer buying behaviour as a set of attitudes characterizing patterns of consumer choices. Solomon et al. (2006) state that consumer buying behaviour represents a study of a process, during which groups or individuals select, purchase, use, and dispose of products of services to satisfy their needs, wants, and desires. Schiffman et al. (2007) claim that consumer buying behaviour is behaviour that any consumer displays in searching, purchasing, using, and disposing of products the consumer expects to satisfy his or her needs, wants, and desires. 
Analysis of consumer buying behaviour has been in the focus of many authors for a long time. Foxall (2001) defines consumer buying behaviour analysis as a synthesis of behavioural economics and real-world complexities of consumer choices in the marketing-oriented economy. These analyses, based on Wells and Foxall (2011), developed principally in response to cognitive domination of customer behaviour research off their needs and wants to explore patterns of customer choice. The core of consumer behaviour analysis was developed together with other behaviour theories focusing on the understanding of psychological and other phenomena (Foxall 2010). The elementary of consumer buying behaviour represents three terms discriminative stimulus, response, and reward. In these terms, consumer buying behaviour analysis represents an interdisciplinary approach to customer choice. The consumer buying behaviour analysis include technology, psychology and business schools (Wells and Foxall 2011).

Chiu, Chen, Tzeng, and Shyu (2006) claim that the traditional basic concept of the marketing strategy employs decision making and many methods used to detect factors influencing customer buying behaviour and decisions. Furthermore, as stated above, any institution can survive without a good marketing strategy since this strategy is essential to marketing planning a decision making of any institution and is dependent on the product, customer behaviour, marketing communication, etc.

Customer buying behaviour is closely connected with marketing since marketing focuses on customer satisfaction as well as institutional goals. Marketing decisions and tactics are connected with the understanding of customer needs, wants, and desires, as well as developing the right products or services for the right customers, informing the organization's customers about the availability of the company offer and possibilities of delivery, or exchange process. (Haghshenas et al. 2013).

There are several different approaches to the study of consumer buying behaviour and consumer decision making. Foxall (1990) distinguishes five main approaches to studying consumer behaviour as follow:

- Behaviourist

- Cognitive

- Economic Man

- Humanist

- Psychodynamic

One of the oldest approaches is the behaviourist approach that was published in the study of Watson in the 1920s. This study tries to prove that consumer behaviour is learned during consumer life (Watson et al. 1920). The cognitive approach is based on the elements and rules of the Cognitive Psychology that dates back to Plato, or Aristoteles 350 B. C. Descartes followed the works of Plato and Aristoteles in his works, and today cognitive approach follows these works and develop the study of the Stimulus Organism Response (Cziko 2000). There are two main cognitive models of consumer buying behaviour - analytical model and cognitive model. These models identify factors 
influencing consumer buying behaviour and typically tend to the traditional five-step calcification. The five-step classification of consumer buying behaviour outline recognition of the problem, information search, evaluation of alternatives, the choice from the alternative, evaluation of outcomes. These steps represent elementary stages in the consumer buying behaviour process (Schiffman et al. 2007). There are many cognitive models of customer buying behaviour, e.g. Analytic Cognitive Models based on the Theory of buying behaviour, The Model of Goal-Directed Behaviour, Consumer Decision Model known as the Engel-Blackwell-Miniard Model, Theory of Reasoned Action, or Prescriptive Cognitive Models based on the Theories of Reasoned Action (TRA) and Planned Behaviour (TPB) - e. g. Fishbein Model and many others.

First, researches regarded men as individually rational and self-interested, making the decision. Based on several researches, the theory of the Economic Man was developed. Based on this model, the customer reacts rationally in the economic sense. The consumer is aware of all available options and selects the optimal one based on the economic aspects (Schiffman et al. 2007).

Theory of Trying represents one of the Humanic models that provides an alternate approach to models previously mentioned. Based on this model, past consumer buying behaviour influence future consumer choice (Bagozzi et al. 1990).

\section{Factors influencing consumer buying behaviour}

As stated above, many types of research are focusing on the customer buying behaviour and factors that influencing consumer buying behaviour.

Dumaz (2014) claims that the main factors influencing the consumer buying behaviour are psychological factors connected with motivation, learning (experiential or conceptual), beliefs, and attitudes. Łatuszyńska, Furaiji, and Wawrzyniak (2012) indicate many internal and external factors influencing consumer buying behaviour as many other authors - for detail, follow the next table.

Tab. 1: General factors influencing consumer buying behaviour

\begin{tabular}{|l|l|}
\hline Author & \multicolumn{1}{c|}{ Factors } \\
\hline \multirow{3}{*}{ Łatuszyńska, Furaiji, and Wawrzyniak (2012) } & $\begin{array}{l}\text { 4Ps (product, price place promotion) } \\
\text { Internal (Beliefs, attitudes, values, Learning, } \\
\text { Motives, Leeds, Perception, Personality, } \\
\text { Lifestyle) } \\
\text { Other (demographic, economic, situational, } \\
\text { lifestyle, social) }\end{array}$ \\
\hline Keegan (1995) & $\begin{array}{l}\text { social, cultural, economic, personal, and } \\
\text { geographic }\end{array}$ \\
\hline Kotler and Armstrong (2007) & physical, social, cultural, and personal \\
\hline Pride and Ferrell (2000) & social, physical, demographic, and attitudinal \\
\hline
\end{tabular}

Source: Łatuszyńska, Furaiji, and Wawrzyniak (2012), Keegan (1995), Kotler and Armstrong (2007), Pride and Ferrell (2000). 
This table involved only several authors focusing on the factors influencing consumer buying behaviour, but we can see that demographic and personal factors are one of the most frequently mentioned.

Lots of authors focusing on the impact of general factors on other factors of consumer buying behaviour - e.g. customer satisfaction, quality, trust, expectation, customer and brand loyalty, price sensitivity, previous experience and many other (Bilal et al. 2010, Ukenna et al. 2012, Petruzzellis, Romanazzi and Gurrieri 2014, and many others).

Dick and Basu (1994) view customer loyalty as the strength of the relationship between an individual customer relative attitude and repeat patronage. Based on Jacoby and Chestnut (1978), there are more than 50 definitions of customer and brand loyalty in the literature in the 1970s. Nowadays, there are many different approaches to customer loyalty. Celuch, Goodwin, and Taylor (2007) define customer loyalty based on the Theory of Planned Behaviour. Moreover, Aaker and Keller (1990) interconnect customer loyalty with various factors - such as experience or brand. Lewis (1997) defined price sensitivity as consumers price perceptions determined by levels of consumer resistance as they relate to perceived quality. Customer expectation is very closely connected with previous customer experience. Both of these factors influence the brand and customer loyalty. Customer satisfaction is influenced usually by trust and previous experience with the brand (Kharim 20114).

According to Foster and Cadogan (2002), price is one of the most critical factors that is considered during the customer buying decision process by the average customer. Loyal customers are willing to pay higher prices for the product and its quality that encompasses characteristics and features of a product that bears on its ability to satisfy customer needs and wants (Russell and Taylor 2006).

\section{Methods and data}

Customer preferences change during each customer's life cycle. One of the critical factors that influence these preferences is precisely age. That is why the author focuses on this aspect - age in the article. In the research, the author deals with the influence of age on consumer decision-making and buying behavior. Age is closely connected with the customer life cycle; therefore, the author involved in her marital research status, number of family members, and monthly income. The other factors will be examined separated in the following papers of the author.

Based on the literature search author generated the first initial version of the marketing research. The author focuses on the consumer buying behavior based on the predestinated characteristics, and less effort is devoted to other characteristics of consumer buying behavior. The main aim is to explore the impact of the age of the customer attitude to price, branded and non-branded goods, and customer loyalty. 
The primary author's method for obtaining data was a questionnaire. Thirty-five questionnaires were excluded from the final evaluation because of incomplete of the questionnaire or incorrect answer. The final size of this paper is 350 questionnaires.

The questionnaire used as the main tool for collecting primary data was divided into three main parts as follows:

1. general questions on consumer buying behaviour.

2. questions on the perception of price.

3. demographic information, including age, and another characteristic - for detail see Tab 4. Demographic profile of respondents

A set of statements was submitted to respondents. Respondents should assess the level of agreement with these statements on the five-point Likert scale with the following measurement: 1 indicates strongly agree, 2 indicates agree, 3 indicates neutral, 4 indicates disagree, 5 indicates strongly disagree.

In this article, the author will use one-way ANOVA to determine whether there is a statistically significant relationship between independent variables (age and customer attitude to price, branded and non-branded goods, and customer loyalty). The author will use ANOVA since the ANOVA is considered as a statistically appropriate test for testing more than two groups measured on some interval scale (in this case, five-point Likert scale). ANOVA determines the variability of the sample.

The statements were divided into groups based on the evaluated factors - attitude to the branded and non-branded goods, attitude to price, and customer loyalty. Based on the literature search of mainly foreign scientific papers and researches, the author selected four statements for attitude to price and four statements for attitude to branded and nonbranded goods and customer loyalty. For detail, see the following table.

Tab 3: Ranking statements

\begin{tabular}{|l|l|}
\hline Factor & Statement \\
\hline Attitude to price & S1: Price is an essential factor for my buying decision \\
\cline { 2 - 2 } & S2: Price reduction motivates me to buy the product \\
\cline { 2 - 2 } & $\begin{array}{l}\text { S3: In the case of buying a more expensive product, the price does not affect my } \\
\text { decision }\end{array}$ \\
\cline { 2 - 2 } & S4: I am a price-sensitive customer \\
\hline \multirow{2}{*}{$\begin{array}{l}\text { Attitude to branded and non- } \\
\text { branded goods and customer }\end{array}$} & S1: I consider myself as a loyal customer \\
\cline { 2 - 2 } loyalty & S2: I prefer branded goods \\
\cline { 2 - 2 } & S3: I prefer non-branded products \\
\cline { 2 - 2 } & S4: I prefer products with which I have a good previous experience \\
\hline
\end{tabular}

Source: Author's research. 
Moreover, author will use chi-square test for testing of the following hypotheses:

$\mathrm{HO}_{1}$ : The preference of branded goods is independent on the age

$\mathrm{H}_{2}$ : The preference of non-branded goods is independent on the age

The chi-square test is a statistical method for testing the independency of data for comparison of observed data with expected to a specific hypothesis. The formula for calculation of chi-square test follows.

$$
\chi^{2}=\sum_{i=1}^{k} \frac{\left(X_{i}-N p_{i}\right)^{2}}{N p_{i}}
$$

\section{Results and Discussion}

As stated above, the final sample for this article was 350 respondents. Necessary information was sorted via descriptive statistics. This information about the sample is summarized in the following table. Among the 350 valid samples, the percentages of women and men are $56 \%$ and $44 \%$, respectively, with more female subjects than male subjects. In terms of age, the largest age group belongs between 25 and 34 years, following 35 and 44 years. The smallest group of subjects is over 64 years old. The largest group in terms of education is the group of a bachelor's degree.

Tab 4: Demographic profile of respondents

\begin{tabular}{|c|c|c|c|}
\hline Characteristic & Type & Absolut frequency & Relative frequency \\
\hline \multirow{6}{*}{ Age } & $16-24$ & 52 & $15 \%$ \\
\hline & $25-34$ & 95 & $27 \%$ \\
\hline & $35-44$ & 74 & $21 \%$ \\
\hline & $45-54$ & 56 & $16 \%$ \\
\hline & $55-64$ & 48 & $14 \%$ \\
\hline & $64+$ & 25 & $7 \%$ \\
\hline \multirow{5}{*}{$\begin{array}{l}\text { The average income per } \\
\text { month }\end{array}$} & less than $10,000 \mathrm{CZK}$ & 30 & $9 \%$ \\
\hline & $10,001-20,000 \mathrm{CZK}$ & 95 & $27 \%$ \\
\hline & $20,001-30,000 \mathrm{CZK}$ & 133 & $38 \%$ \\
\hline & $30,001-40,000 \mathrm{CZK}$ & 53 & $15 \%$ \\
\hline & $40,000 \mathrm{CZK}$ and more & 39 & $11 \%$ \\
\hline \multirow{4}{*}{ Marital status } & single & 152 & $43 \%$ \\
\hline & married & 156 & $45 \%$ \\
\hline & divorce & 38 & $11 \%$ \\
\hline & widow & 4 & $1 \%$ \\
\hline \multirow{5}{*}{ Number of a family member } & 1 & 38 & $11 \%$ \\
\hline & 2 & 89 & $25 \%$ \\
\hline & 3 & 89 & $25 \%$ \\
\hline & 4 & 132 & $38 \%$ \\
\hline & 5 and more & 2 & $1 \%$ \\
\hline
\end{tabular}

Source: Author's research.

The following table summarised ranking statements based on the respondents' evaluation on the Likert scale. 
Tab 5: Ranking statements

\begin{tabular}{|c|c|c|c|}
\hline Factor & Statement & Mean & $\begin{array}{l}\text { Standard } \\
\text { deviation }\end{array}$ \\
\hline \multirow[t]{4}{*}{ Attitude to price } & S1: Price is an essential factor for my buying decision & 2.325 & 1.010 \\
\hline & S2: Price reduction motivates me to buy the product & 2.452 & 1.159 \\
\hline & $\begin{array}{l}\text { S3: In the case of buying a more expensive product, the price } \\
\text { does not affect my decision }\end{array}$ & 2.891 & 1.320 \\
\hline & S4: I am a price-sensitive customer & 3.211 & 1.980 \\
\hline \multirow{4}{*}{$\begin{array}{l}\text { Attitude to } \\
\text { branded and non- } \\
\text { branded goods and } \\
\text { customer loyalty }\end{array}$} & S1: I consider myself as a loyal customer & 2.960 & 0.895 \\
\hline & S2: I prefer branded goods & 1.963 & 0.056 \\
\hline & S3: I prefer non-branded products & 2.963 & 0.198 \\
\hline & $\begin{array}{l}\text { S4: I prefer products with which I have a good previous } \\
\text { experience }\end{array}$ & 1.895 & 0.369 \\
\hline
\end{tabular}

Source: Author's research.

As we can see from the table above most of the respondents prefer branded goods (with the lowest standard deviation). Major of the respondents stated that they are not pricesensitive customers, but the standard deviation of this statement is the highest among the others.

One-way ANOVA analysis between age and other factor was executed. The results of the ANOVA table are summarized in the following table and text.

Tab 6: Age versus evaluated statements concerning price

\begin{tabular}{|l|l|l|l|l|l|l|}
\hline \multicolumn{1}{|c|}{ Statement } & \multicolumn{5}{c|}{ Age (Mean) } \\
\cline { 2 - 7 } & $16-24$ & $25-34$ & $35-44$ & $45-54$ & $55-64$ & $64+$ \\
\hline $\begin{array}{l}\text { S1: Price is an essential factor for my buying } \\
\text { decision }\end{array}$ & 3.012 & 2.695 & 1.896 & 2.109 & 2.963 & 1.269 \\
\hline $\begin{array}{l}\text { S2: Price reduction motivates me to buy the } \\
\text { product }\end{array}$ & 1.968 & 2.986 & 2.1036 & 1.968 & 2.560 & 3.129 \\
\hline $\begin{array}{l}\text { S3: In the case of buying a more expensive } \\
\text { product, the price does not affect my decision }\end{array}$ & 3.156 & 1.963 & 2.986 & 2.968 & 2.789 & 3.489 \\
\hline S4: I am a price-sensitive customer & 3.569 & 2.968 & 3.456 & 3.968 & 2.997 & 1.896 \\
\hline
\end{tabular}

Source: author's research.

As stated above, the author executed a one-way between groups analysis of variance to explore the impact of age on ranking statements (these statements were measured by the Likert scale). All respondents were divided into six groups according to their age). ANOVA revealed statistically significant differences at the confidence level of $95 \%$ for statement 1 Price is an essential factor for my buying decision between group 16-24, 55-64, and 64+ $(\mathrm{F}(5,350)=2,33, \mathrm{p}=0.0031)$. Another significant difference at the $\mathrm{p}$-value 0,05 was revealed for statement 3 In the case of buying a more expensive product, the price does not affect my decision mainly for age groups $16-24,25-34$ and $64+(F(5,350=3,2$, $\mathrm{p}=0.00112$ ) and for statement $4 \mathrm{I}$ am a price-sensitive customer $16-24,25-34,45-$ 54 and $64+(F(5,350=2.9, p=0.00212)$.

Despite the fact that most of the respondents (except age group 64+) stated that they do not agree with the stamen that they are price-sensitive customers - for detail see 
following graph, author's research revealed that that the most price-sensitive group is group $64+$, followed by the age group $35-44$.

Figure 1: I am a price-sensitive customer

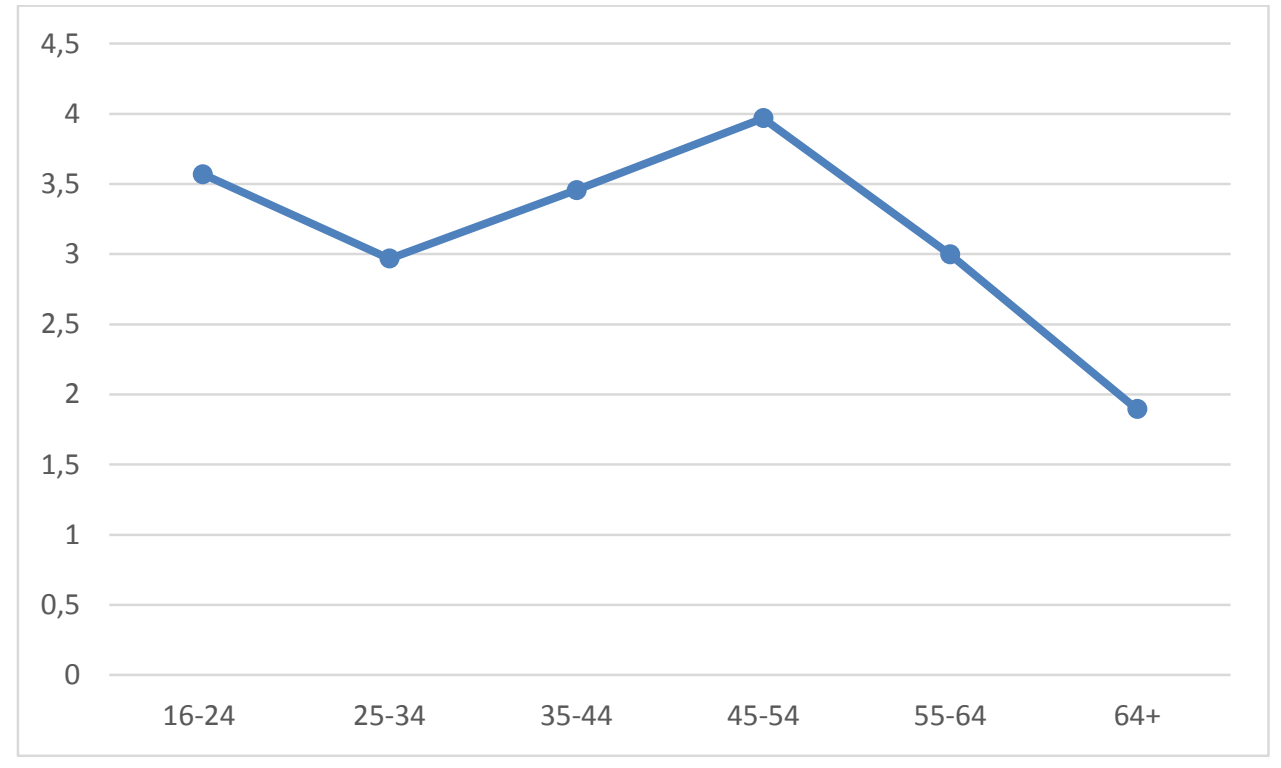

Source: Author's research.

\section{Results of the chi-square test}

The author tested the following hypotheses:

$\mathrm{HO}_{1}$ : The preference of branded goods is independent on the age

$\mathrm{H}_{2}$ : The preference of non-branded goods is independent on the age

Both hypotheses were tested at the $95 \%$ confidence level. In both cases the p-value is less than 0.05 . Therefore, we can reject the null hypothesis that the preference of branded and non-branded goods is independent on the age. P-value for $\mathrm{H}_{1}$ is 0,00326 and $\mathrm{p}$-value for $\mathrm{H}_{2}$ is 0,00126 .

\section{Conclusion}

The finding of the author's research revealed that age is one of the factors influencing consumer buying behaviour and attitude of the customer to price. The most pricesensitive consumer group is the oldest age group, 64+. ANOVA analysis proved that there are statistically significant differences among several age groups (statements 1, 3, and 4). The chi-squared test proved that preferences of branded and non-branded goods is not independent on the age.

As stated above, age is one of the factors connected with the consumer life cycle that influencing consumer buying behaviour. In the next research author will focus on other 
aspects of the consumer life cycle - monthly income, number of family members, and marital status.

\section{References}

AAKER, D. A. and Keller, K. L., 1990. Consumer Evaluations of Brand Extensions. Journal of Marketing. 54(1), 27. doi: 10.2307/1252171

BAGOZZI, R. et al., 1990. Trying to Consume. Journal of Consumer Research. 17(2), 127140.

BILAL, A. et al., 2010. Determinants of customer loyalty in the banking sector: The case of Pakistan. Journal of Business Management. 4(6), 1040-1047.

CELUCH, K., GOODWIN, S. and TAYLOR, S. A., 2007. Understanding small scale industrial user internet purchase and information management intentions: A test of two attitude models. Industrial Marketing Management. 36(1), 109-120. doi:

10.1016/j.indmarman.2005.08.004

CRANFIELD, J., HENSON, S., and BLANDON, J., 2012. The Effect of Attitudinal and Sociodemographic Factors on the Likelihood of Buying Locally Produced Food. Agribusiness, 28(2), 205-221. doi: 10.1002/agr.21291

CZIKO, G., 2000. The things we do: Using the lessons of bernard and darwin to understand the what, how and why of our behaviour. The MIT Press, Cambridge, Massachusetts, 290 Pp. ISBN 0-262-03277-5, Price (Cloth), \$37.95." Journal of Mammalogy. 82(3), 882-883., doi:10.1093/jmammal/82.3.882a.

DAWSON, J. A., FINDLAY, A., and SPARKS, L., 2008. The retailing reader. London: Routledge.

DICK, A. S. and BASU, K., 1994. Customer Loyalty: Toward an Integrated Conceptual Framework. Journal of the Academy of Marketing Science, 22(2), 99-113. doi:

10.1177/0092070394222001

DURMAZ, Y., 2014. The Impact of Psychological Factors on Consumer Buying Behaviour and an Empirical Application in Turkey. Asian Social Science. 10(6), 194-204 doi: 10.5539/ass.v10n6p194

DURMAZ, Y., 2014. The Impact of Psychological Factors on Consumer Buying Behaviour and an Empirical Application in Turkey. Asian Social Science, 10(6), ,doi:10.5539/ass.v10n6p194.

FOSTER, B. D. and CADOGAN, J. W., 2000. Relationship selling and customer loyalty: an empirical investigation. Marketing Intelligence \& Planning. 18(4), 185-199. doi: $10.1108 / 02634500010333316$

FOXALL, G. R., 2010. Invitation to Consumer Behaviour Analysis. Journal of Organizational Behaviour Management. 30(2), 92-109. doi: 10.1080/01608061003756307

FOXALL, G., 1990. Consumer Psychology in Behavioural Perspective. London: Routledge. FOXALL, G. R., 2001. Consumer behaviour analysis: Critical perspectives on business and management. London: Routledge. 
HAGHSHENAS, L., ABEDI, A. and GHORBANI, E., 2013. Review Consumer Behaviour and Factors Affecting on Purchasing Decisions. Singaporean Journal of Business, Economics and Management Studies. 1(10), 17-24. doi: 10.12816/0003798

HAGHSHENAS, L. et al., 2013. Review Consumer Behaviour and Factors Affecting on Purchasing Decisions. Singaporean Journal of Business, Economics and Management Studies. 1(10), 17-24., doi:10.12816/0003798.

HERVÉ, C. and Mullet, E., 2009. Age and factors influencing consumer behaviour. International Journal of Consumer Studies. 33(3), 302-308. doi: 10.1111/j.14706431.2009.00743.x

HOMER, P. M. and KAHLE, L. R. 1988. A structural equation test of the value attitude behaviour hierarchy. Journal of Personality and Social Psychology. 54(4), 638-646. doi: 10.1037/0022-3514.54.4.638

CHHABRA, D., 2018. Factors Affecting Consumer Buying Behaviour and Decision Making Process towards FMCG Products. Journal of Advances and Scholarly Researches in Allied Education, 15(6), 131-139. doi: 10.29070/15/57735

CHIU, Y.-J., CHEN, H.-C., TZENG, G.-H. and SHYU, J. Z., 2006. Marketing strategy based on customer behaviour for the LCD-TV. International Journal of Management and Decision Making, 7(2/3), 143. doi: 10.1504/ijmdm.2006.009140

JACOBY, J. and CHESTNUT. R. W., 1978. Brand Loyalty Measurement and Management.

New York: Wiley.

KEEGAN, W., MORIARTY, S. and DUNCAN, T., 1992. Marketing. Englewood Cliffs, NJ: Prentice-Hall

KHANIWALE, M., 2015. Consumer Buying Behaviour. International Journal of Innovation and Scientific Research. 14(2), 278-286

KHRAIM, H. S., 2011. The Influence of Brand Loyalty on Cosmetics Buying Behaviour of UAE Female Consumers. International Journal of Marketing Studies. 3(2). doi: 10.5539/ijms.v3n2p123

KOTLER, P. and ARMSTRONG, G., 2007. Principles of Marketing. Upper Saddle River, NJ: Prentice Hall.

KUMAR, V., HUNDAL, B. S. and KAUR, K., 2019. Factors affecting consumer buying behaviour of solar water pumping system. Smart and Sustainable Built Environment. 8(4), 351-364. doi: 10.1108/sasbe-10-2018-0052

ŁATUSZYŃSKA, M. Ł. M., FURAIJI, F. F. F. and WAWRZYNIAK, A. W. A., 2012. An Empirical Study of the Factors Influencing Consumer Behaviour in the Electric Appliances Market. Contemporary Economics. 6(3), 76. doi: 10.5709/ce.1897-9254.52

LAWAN, L. and ZANNA, R., 2013. Evaluation of Socio-Cultural Factors Influencing Consumer Buying Behaviour of Clothes in Borno State, Nigeria. International Journal of Basic and Applied Science. 1(3), 519-529. doi: 10.17142/ijbas-2012.1.3.7

LEWIS, R., 1997. Price-sensitivity measurement A tool for the hospitality industry. The Cornell Hotel and Restaurant Administration Quarterly. 38(2), 44-54. doi:

10.1016/s0010-8804(97)81475-9

LICHEV, G. T., 2017. Psychological Factors in Determining Consumer Behaviour. Eastern Academic Journal. 1(3), 8-16 
MARTINS, J. M., YUSUF, F. and SWANSON, D. A., 2011. Demographic Perspectives on Consumer Behaviour and Implications for the Future. Consumer Demographics and Behaviour The Springer Series on Demographic Methods and Population Analysis, 197-208. doi: 10.1007/978-94-007-1855-5_12

MCGUIRE, W. J., 1976. Some Internal Psychological Factors Influencing Consumer Choice. Journal of Consumer Research, 2(4), 302. doi: 10.1086/208643

OSTROVSKIY, A., GARKAVENKO, V. and RYBINA, L., 2019. Influence of socio-psychological factors on consumers purchasing behaviour in Kazakhstan. The Service Industries Journal, 1-26. doi: 10.1080/02642069.2019.1601707

PETRUZZELLIS, L., ROMANAZZI, S. and GURRIERI, A.R., 2014. Loyalty and customer satisfaction in retail banking the role of social network. Available at: http://www.escpeap.net/conferences/marketing/2008_cp/Materiali/Paper/It/Petruzzellis_Romanazzi_G urrieri.pdf

PRIDE, W. M. and FERRELL, O. C., 2007. Foundations of Marketing (2nd ed.). Boston, MA: Houghton Miffin Company.

RANI, P., 2014. Factors influencing consumer behaviour. International Journal of Current Research and Academic Review, 2(9), 52-61.

REHMAN, F. U., YUSOFF, R. B. M., ZABRI, S. B. M. and ISMAIL, F. B., 2017. Determinants of personal factors in influencing the buying behaviour of consumers in sales promotion: a case of fashion industry. Young Consumers, 18(4), 408-424. doi: 10.1108/yc-06-201700705

RUSSELL, R. S. and TAYLOR, B. W., 2006. Operation Management: Quality and Competitiveness in a Global Environment (5th ed). New Jersey: John Wiley \& Sons, Inc.

SHARMA, M.K., 2014. The Impact on Consumer Buying Behaviour: Cognitive Dissonance. Global Journal of Finance and Management. 6(9), 833-840. ISSN 0975-6477

SCHIFFMAN, L. G., et al., 2007. Consumer Behaviour. 9th ed. New Jersey: Prentice Hall.

SOLOMON, M. et al. 2006. Consumer Behaviour: A European Perspective. 3rd ed. Harlow: Prentice Hall.

STÁVKOVÁ, J., STEJSKAL, L. and TOUFAROVÁ, Z. 2008. Factors influencing consumer behaviour. Agricultural Economics (Zemědělská Ekonomika), 54(6), 276-284. doi: 10.17221/283-agricecon

SUKDEO, N., 2018. Factors that influence consumer behaviour in the purchase of durable household products. Proceedings of the International Conference on Industrial Engineering and Operations Management Paris, France, July 26-27, 2018

TAN, B. Ch., 2011. The Role of Perceived Consumer Effectiveness on Value-AttitudeBehaviour Model in Green Buying Behaviour Context. Australian Journal of Basic and Applied Sciences. 5(12), 1766-1771

UKENNA, S. et al. 2012. Drivers of Bank Loyalty among Students in Nigeria: Positing the 12-Point Student Customer Bank Loyalty Index Model. American Journal of Business and Management. 1(3), 172-176.

WATSON, J. et al., 1920. Conditioned Emotional Reactions. Journal of Experimental Psychology. 3(1) 1-14. 
WELLS, V. K. and Foxall, G. R., 2011. Special issue: Consumer behaviour analysis and services. The Service Industries Journal.31(15), 2507-2513. doi: 10.1080/02642069.2011.531122

YAKUP, D. and JABLONSK, S., 2012. Integrated approach to factors affecting consumers purchasebehaviour in Poland and an empirical study. Global Journal of Management and Business Research, 12(15), 61-87.

ZEPEDA, L., and DEAL, D., 2009. Organic and local food consumer behaviour: Alphabet Theory. International Journal of Consumer Studies, 33(6), 697-705. doi: 10.1111/j.14706431.2009.00814.x

\section{Contact address of the author:}

Ing. Marie Slabá, Ph.D., Institute of Technology and Business in České Budějovice, Faculty of Corporate Strategy, Department of Tourism and Marketing, Okružní 517/10, 37001 České Budějovice, Czech Republic, e-mail: slaba@mail.vstecb.cz 